\title{
Piceatannol inhibits mast cell-mediated allergic inflammation
}

\author{
YU-JIN KO ${ }^{1}$, HUI-HUN KIM ${ }^{1}$, EUN-JUNG KIM ${ }^{1}$, YOSHINORI KATAKURA ${ }^{2}$, \\ WON-SUP LEE ${ }^{3}$, GON-SUP KIM ${ }^{4}$ and CHUNG-HO RYU ${ }^{1}$
}

\author{
${ }^{1}$ Division of Applied Life Sciences (BK 21 Program), Institute of Agriculture and Life Sciences, \\ Gyeongsang National University, Jinju 660-701, Republic of Korea; ${ }^{2}$ Department of Genetic Resources \\ Technology, Faculty of Agriculture, Kyushu University, Higashi-ku, Fukuoka 812-8581, Japan; \\ ${ }^{3}$ Department of Internal Medicine, Institute of Health Sciences and Gyeongnam Regional Cancer Center, \\ Gyeongsang National University School of Medicine, Jinju 660-702; ${ }^{4}$ School of Veterinary Medicine, Research \\ Institute of Life Science, Gyeongsang National University School of Medicine, Jinju 660-701, Republic of Korea
}

Received November 23, 2012; Accepted January 15, 2013

DOI: 10.3892/ijmm.2013.1283

\begin{abstract}
Piceatannol is a phenolic stilbenoid and a metabolite of resveratrol which is found in red wine. Piceatannol (PIC) commonly exhibits anti-inflammatory, antiplatelet and antiproliferative activity. In the present study, the anti-allergic and anti-inflammatory mechanisms of PIC were investigated by examining the effects of PIC on pro-inflammatory cytokine release and phosphorylation of mitogen-activated protein (MAP) kinases (ERK, JNK and p38) in a human mast cell line. PIC dose-dependently inhibited compound 48/80-induced systemic anaphylaxis and immunoglobulin E-mediated local allergic reactions. PIC reduced the immunoglobulin $\mathrm{E}$ ( $\mathrm{IgE}$ )-mediated local allergic reaction and attenuated histamine release from rat peritoneal mast cells. Histamine and $\beta$-hexosaminidase release was markedly decreased dose-dependently by PIC treatment in RBL-2H3 cells. PIC treatments of HMC-1 cells definitely reduced mRNA expression and the release of the pro-inflammatory cytokines, tumor necrosis factor- $\alpha$ and interleukin-8. MAP kinase phosphorylation was also strongly decreased dose-dependently following PIC treatment. PIC regulated the production of cytokines and histamine in phorbol 12-myristate 13-acetate plus A23187-stimulated mast cells. Thus, PIC may alleviate allergic inflammation and may be a useful therapeutic agent for allergic diseases.
\end{abstract}

Correspondence to: Professor Chung-Ho Ryu, Division of Applied Life Sciences (BK 21 Program), Food Science and Technology, Institute of Agriculture and Life Sciences, 900 Gazwa-Dong, Gyeongsangnam-do, Jinju-si 660-701, Republic of Korea

E-mail: ryu@gnu.ac.kr

Key words: piceatannol, allergic inflammation, mast cells, cytokine, MAP kinase

\section{Introduction}

Resveratrol, trans-3,4',5-trihydoxystilbene, which is primarily derived from red grapes, exhibits anti-inflammatory, antiplatelet and antiproliferative activity, in addition to having anti-oxidative properties (1-4). Resveratrol has been reported to suppress the expression of pro-inflammatory markers, including cyclooxygenase (COX)-2, and reduce lipid peroxidation, and tumor initiation, promotion and metastasis (5). Naturally occurring hydroxystilbenes consist of 2 benzene rings connected by an olefin. Piceatannol (PIC) is a trans3,4,3',5-tetra hydroxystilbene first isolated from the seeds of Euphoribia lagascae $(6,7)$. This stilbene has been shown to be a potent inducer of apoptosis through activation of caspase-3, in lymphoma cells and in primary leukemic lymphoblasts derived from childhood acute lymphoblastic leukemia patients (8). Other studies have suggested that PIC is a potent inhibitor of the protein tyrosine kinases $\mathrm{p} 56^{l c k}$ and Syk (8-11), and a potent inhibitor of the following serine/threonine protein kinases: the catalytic subunit of cAMP-dependent protein kinase, phospholipid-dependent protein kinase $\mathrm{C}$ and $\mathrm{Ca}^{2}$-calmodulindependent myosin light-chain kinase (12). PIC has also been shown to block FceR I-mediated signaling in mast cells through the suppression of Syk activity (13). Resveratrol was found to exert a beneficial effect in the treatment of ischemia, and neurodegenerative and allergic diseases $(14,15)$. However, the functional effects of PIC, a metabolite of resveratrol, are not known.

Mast cells are one of the major effector cells in the immune response system. Activated mast cells release pro-inflammatory cytokines, such as tumor necrosis factor (TNF)- $\alpha$, interleukin (IL)-6, IL-8, IL-13 and inflammatory mediators, including histamine, luekotrienes, serotonin, prostaglandin (PG)E2, as well as PGD2 (16-18). Cytokines, such as TNF- $\alpha$, IL-6 and IL-8, are released in a coordinated fashion and play important roles in chronic inflammation. TNF- $\alpha$ is either preformed and stored in granules of mast cells, or is newly synthesized following mast cell activation; it is a multifunctional cytokine and an important mediator of the immune and inflammatory response (19). In contrast, IL-8 from mast cells 
acts on surrounding cells such as neutrophils, T-lymphocytes and eosinophils, and plays a role in the activation of inflammatory effector cells (20).

Calcium $\left(\mathrm{Ca}^{2+}\right)$ acts as a second messenger during cell activation, and an increase in intracellular $\mathrm{Ca}^{2+}$ concentration has been proposed as an essential trigger for mast cell activation $(21,22)$. Moreover, it has been reported that the release of intracellular $\mathrm{Ca}^{2+}$ from internal stores is required for mitogenactivated protein kinase (MAPK) activation (23).

The aim of the present study was to investigate the mechanisms by which PIC affects the production of inflammatory cytokines. This study was conducted using the human mast HMC-1 cell line and the rat basophilic RBL-2H3 leukemia cell line. The effects of PIC were evaluated on phorbol 12-myristate 13-acetate (PMA) plus A23187-induced expression of pro-inflammatory mediators, histamine, $\beta$-hexosaminidase and cytokines, and the inhibition of mitogen-activated protein kinase (MAPK) signaling pathways was analyzed.

\section{Materials and methods}

Animals. The original stock of male ICR mice (20-30 g) was purchased from the Dae-Han Biolink Co. Ltd. (Daejeon, Korea). The animals were maintained in the Laboratory Animal Research Center (LARC) of Gyeongsang National University. The care and treatment of the mice were in accordance with the guidelines established by the Public Health Service Policy on the Human Care and Use of Laboratory Animals and were approved by the Institutional Animal Care and Use Committee.

Reagents. Piceatannol (trans-3,4,3',5'-tetrahydoxystilbene) (PIC) (Fig. 1) was purchased from Sigma-Aldrich and dissolved in dimethyl sulfoxide (DMSO), so that the final PIC concentrations in culture media were 1, 10, 50 and $100 \mu \mathrm{M}$. Compound 48/80, anti-dinitrophenyl (DNP) IgE, DNP-human serum albumin (HSA), pyrrolidine dithiocarbamate (PDTC), phorbol 12-myristate 13-acetate (PMA), the calcium ionophore A23187 (calcimycin) and 3-[4,5-dimethylthiazol-2-yl]-2,5-diphenyltetrazolium bromide (MTT) were purchased from Sigma-Aldrich (St. Louis, MO, USA). The easy-BLUE ${ }^{\mathrm{TM}}$ Total RNA Extraction kit was purchased from Intron Biotechnology. Iscove's modified Dulbecco's medium (IMDM) and Dulbecco's modified Eagle's medium (DMEM) were obtained from Gibco BRL (Grand Island, NY, USA). Anti-human TNF- $\alpha$ and IL- 8 antibodies, and biotinylated anti-human TNF- $\alpha$ and IL-8 antibodies were obtained from BD Pharmingen (San Diego, CA, USA); antibodies to ERK, p-ERK, JNK, p-JNK, p38 and p-p38 were obtained from Cell Signaling (Beverly, MA, USA).

Compound 48/80-induced systemic anaphylaxis. As an in vivo model for the immediate-type allergic reaction, compound 48/80-induced systemic reaction was carried out as previously described (24). Briefly, the mice (n=10/group) received an intraperitoneal injection of $8 \mathrm{mg} / \mathrm{kg}$ body weight (BW) of the mast cell degranulator, compound 48/80. PIC was dissolved in saline and administered intraperitoneally at doses of $10-1000 \mathrm{mg} / \mathrm{kg} \mathrm{BW} 1 \mathrm{~h}$ before the compound 48/80 injection. In the time-dependent experiment, PIC $(1000 \mathrm{mg} / \mathrm{kg})$

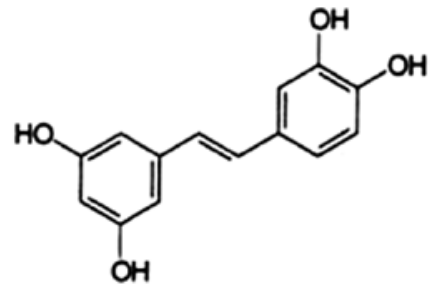

Figure 1. Chemical structure of piceatannol. Molecular weight, 244.2.

was administered 5, 10, 15 and 20 min after compound 48/80 injection ( $\mathrm{n}=10 /$ group). Mortality was monitored for $1 \mathrm{~h}$ after induction of anaphylactic shock.

Passive cutaneous anaphylaxis (PCA). PCA reaction was carried out as previously described (25). Briefly, mice were injected intradermally with $0.5 \mu \mathrm{g}$ of anti-DNP IgE. After $48 \mathrm{~h}$, each mouse ( $\mathrm{n}=10 /$ group) received an injection of $1 \mathrm{mg}$ of DNP-HSA in PBS containing 4\% Evans blue (1:1) via the tail vein. PIC (10-1000 mg/kg BW) was intraperitoneally administered $1 \mathrm{~h}$ before the challenge. Thirty minutes after the challenge, the mice were sacrificed and the dorsal skin (diameter, $1 \mathrm{~cm}$ ) was removed in order to measure the pigment area. The amount of dye was determined colorimetrically after extraction with $1 \mathrm{ml}$ of $1 \mathrm{M} \mathrm{KOH}$ and $9 \mathrm{ml}$ of a mixture of acetone and phosphoric acid (5:13). The intensity of the absorbent was measured at $620 \mathrm{~nm}$ in a spectrophotometer (Biochrom Libra S22 UV; Biochrom, Holliston, MA, USA).

Cell culture. The human mast cell line HMC-1 (a kind gift from Dr H.M. Kim of Kyeonghee University, Seoul, Korea) was grown in IMDM, supplemented with $100 \mathrm{U} / \mathrm{ml}$ penicillin, $100 \mu \mathrm{g} / \mathrm{ml}$ streptomycin and $10 \%$ heat-inactivated fetal bovine serum (FBS), in a humidified incubator at $37^{\circ} \mathrm{C}$ in $5 \% \mathrm{CO}_{2}$. The adherent rat basophilic leukemia RBL-2H3 1 cell line (Korean Cell Line Bank no. 22256) was grown as a monolayer culture in complete DMEM (containing 10\% heat-inactivated fetal bovine serum, $4 \mathrm{mM} \mathrm{L}$-glutamine, $100 \mathrm{U} / \mathrm{ml}$ penicillin and $100 \mu \mathrm{g} / \mathrm{ml}$ streptomycin). For experiments, the cells were detached by trypsinization, washed once with complete DMEM, once with serum-free DMEM, and then were resuspended in serum-free DMEM.

Treatment of cells with PIC. HMC-1 and RBL-2H3 cells were treated with PIC $(1,10,50$ and $100 \mu \mathrm{M})$ for $30 \mathrm{~min}$. The cells were then stimulated by $50 \mathrm{nM}$ of PMA plus $1 \mu \mathrm{M}$ of A23187 and incubated at $37^{\circ} \mathrm{C}$ for the indicated time periods.

MTT assay. Cell viability was determined by an MTT assay. Briefly, cells were pretreated with various concentrations of PIC $(1,10,50$ and $100 \mu \mathrm{M})$ for $30 \mathrm{~min}$ and then incubated for $12 \mathrm{~h}$ in the absence or presence of PMA plus A23187. After a 12-h incubation, $50 \mu \mathrm{l}$ of MTT solution was added to the culture (total volume, $500 \mu \mathrm{l}$ ). After an 8-h incubation, the absorbance was measured at $540 \mathrm{~nm}$ with a microplate reader (PRS Scientific LLC, Frederick, MD, USA). The absorbance correlates with cell viability, and the number of cells (\% of control) was calculated using the following formula: Cell number $(\%$ of control $)=($ absorbance of treated 
Table I. Primers and PCR conditions for analysis of gene expression in the HMC-1 cells.

\begin{tabular}{|c|c|c|c|c|}
\hline & Primer sequence ( $\left.5^{\prime}-3^{\prime}\right)$ & $\begin{array}{c}\text { Annealing } \\
\text { temperature }\left({ }^{\circ} \mathrm{C}\right)\end{array}$ & $\begin{array}{l}\text { Number of } \\
\text { cycles }\end{array}$ & $\begin{array}{l}\text { Amplified fragment } \\
\text { sizes (bp) }\end{array}$ \\
\hline \multirow[t]{2}{*}{ TNF- $\alpha$} & 5'-CGGGACGTGGAGCTGGCCGAGGAG-3' & & & \\
\hline & 5'-CACCAGCTGGTTATCTCTCAGCTC-3' & 57 & 35 & 355 \\
\hline \multirow[t]{2}{*}{ IL-8 } & 5'-TGAATTCTCAGCCCTCTTCAAAAA-3' & & & \\
\hline & 5'-CGATGTCAGTGCATAAAGACA-3' & 59 & 35 & 443 \\
\hline \multirow[t]{2}{*}{ GADPH } & 5'-CCTGCTTCACCACCTTCTTG-3' & & & \\
\hline & 5'-CAAAAGGGTCATCATCTCTG-3' & 60 & 30 & 446 \\
\hline
\end{tabular}

cells - absorbance of blank well)/(absorbance of control cells - absorbance of blank well) $\mathrm{x}$ 100. The control was not treated, and the blank control consisted of PMA- plus A23187-stimulated HMC-1 cells without PIC treatment.

Histamine assay. Preparation of serum and determination of histamine contents were performed as previously described (26). Trypsinized RBL-2H3 cells were resupended in serum-free DMEM $\left(1 \times 10^{6}\right.$ cells $\left./ \mathrm{ml}\right)$ in a $24-w e l l$ cell culture plate and stabilized for $1 \mathrm{~h}$ in an incubator. The cells were pretreated with various concentrations of PIC $(1,10,50$ and $100 \mu \mathrm{M}$ ) for $30 \mathrm{~min}$ and then incubated for $8 \mathrm{~h}$ with PMA plus A23187. After treatments, the cell suspensions were centrifuged at $13,000 \mathrm{x} \mathrm{g}$ for $5 \mathrm{~min}$ and the pellets were discarded. The concentrations of released histamine were determined using a histamine enzyme immunoassay kit (Oxford Biomedical Research, Oxford, MI, USA), and 50- $\mu 1$ samples of supernatants were tested following the manufacturer's instructions. Fifty microliter samples or the standard, plus the enzyme conjugate were added to the 96-well plate of the kit, which was coated with monoclonal antibody, followed by incubation for $45 \mathrm{~min}$ at room temperature. The plate was then washed 3 times, and after the addition of $150 \mu \mathrm{l}$ of tetramethylbenzidine (TMB) substrate, it was incubated for 15-20 min. The reaction was stopped using $50 \mu 1$ of $1 \mathrm{~N} \mathrm{HCl}$, and the absorbance was read at $450 \mathrm{~nm}$. All subsequent steps took place at room temperature, and all standards and samples were assayed in triplicate.

$\beta$-hexosaminidase release assay. Mast cell degranulation was determined by measuring the release of a granule marker, $\beta$-hexosaminidase. RBL-2H3 cells were seeded into 24 -well plates $\left(1 \times 10^{6}\right.$ cells/well) and incubated overnight. Cells were washed 3 times with Siraganian buffer $(125 \mathrm{mM} \mathrm{NaCl}, 5 \mathrm{mM}$ $\mathrm{KCl}, 1.5 \mathrm{mM} \mathrm{CaCl}_{2}, 1.5 \mathrm{mM} \mathrm{MgCl}$, $20 \mathrm{mM}$ HEPES, pH 7.3). The cells were then stimulated with $400 \mathrm{ng} / \mathrm{ml}$ dinitrophenolbovine serum albumin (DNP-BSA) (Sigma-Aldrich) suspended in $500 \mu \mathrm{l}$ Siraganian buffer containing $0.1 \%$ BSA, and incubated at $37^{\circ} \mathrm{C}$ for $1 \mathrm{~h}$. Following incubation, $50 \mu \mathrm{l}$ samples of the cell culture supernatant were each incubated with $200 \mu$ of $1 \mathrm{mM}$ p-nitrophenyl $\mathrm{N}$-acetyl- $\beta$-D-glucosamine (Sigma) in $0.05 \mathrm{M}$ citrate buffer ( $\mathrm{pH} 4.5$ ) for $3 \mathrm{~h}$ at $37^{\circ} \mathrm{C}$. The enzyme reaction was terminated by the addition of $500 \mu \mathrm{l}$ of $0.05 \mathrm{M}$ sodium carbonate buffer ( $\mathrm{pH} 10.0$ ), and the absorbance of each reaction was determined at $405 \mathrm{~nm}$.
The effects of various treatments on $\beta$-hexosaminidase release were described as the percentage of the IgE-only control absorbance value: $\%$ of inhibition $=($ Treated - Blank - Spontaneous)/(Control - Blank - Spontaneous); Control, normal allergen-IgE response evoked with test material not added; Treated, normal allergen-IgE response evoked with test material added; Blank, only test material and substrate added to ELISA well; Spontaneous, allergen-IgE response was not evoked with test material not added.

Cytokine assay. The secretion of TNF- $\alpha$ and IL-8 was measured by an enzyme-linked immunosorbent assay (ELISA). HMC-1 cells were stimulated with PMA (50 nM) and A23187 $(1 \mu \mathrm{M})$ for $8 \mathrm{~h}$ with or without PIC. The ELISA was performed by coating 96 -well plates with $6.25 \mathrm{ng} /$ well of monoclonal antibodies with specificity for TNF- $\alpha$ or IL-8. Before use and between subsequent steps in the assay, the coated plates were washed twice with washing buffer (PBS containing $0.05 \%$ Tween-20). For the standard curve, recombinant TNF- $\alpha$ and IL- 8 were added to serum which was previously determined to be negative for endogenous TNF- $\alpha$ and IL-8. After exposure to the cell supernatant from the experiment, the assay plates were exposed sequentially to biotinylated 2,2' azino-bis (3-ethylbenzthiazoline-6-sulfonic acid) substrate. The absorbances at $405 \mathrm{~nm}$ were determined within $10 \mathrm{~min}$ after addition of the substrate. All subsequent steps took place at room temperature, and all standards and samples were assayed in triplicate.

Reverse transcription-polymerase chain reaction (RT-PCR) analysis. HMC-1 cells $\left(1 \times 10^{6} / \mathrm{ml}\right)$ were pretreated with PIC for $30 \mathrm{~min}$ before PMA $(50 \mathrm{nM})$ plus A23187 $(1 \mu \mathrm{M})$ stimulation for $2 \mathrm{~h}$. Total RNA was isolated according to the manufacturer's specifications using an easy-BLUE RNA extraction kit. The concentration of total RNA was determined by spectrophotometry. Each sample was reverse transcribed to cDNA for $60 \mathrm{~min}$ at $45^{\circ} \mathrm{C}$ using a cDNA synthesis kit (Amersham Biosciences, Piscataway, NJ, USA). The primers and PCR conditions are shown in Table I. Products were electrophoresed on a $1.5 \%$ agarose gel and visualized by staining with ethidium bromide. The gels were photographed using a Kodak DC 290 digital camera (Eastman Kodak, Rochester, NY, USA) and digitized using UN-SCAN-IT software (Silk Scientific, Orem, UT, USA). Relative band intensity was analyzed by using ImageJ image analyzing software. 
Table II. Effect of PIC on compound 48/80-induced systemic anaphylaxis.

\begin{tabular}{lcc}
\hline $\begin{array}{l}\text { PIC treatment } \\
(\mathrm{mg} / \mathrm{kg} \mathrm{BW})\end{array}$ & $\begin{array}{c}\text { Compound 48/80 } \\
(8 \mathrm{mg} / \mathrm{kg} \mathrm{BW})\end{array}$ & $\begin{array}{c}\text { Mortality } \\
(\%)\end{array}$ \\
\hline None (saline) & + & 100 \\
10 & + & 100 \\
50 & + & 100 \\
100 & + & 70 \\
500 & + & 40 \\
1000 & + & 0 \\
1000 & - & 0 \\
\hline
\end{tabular}

Groups of mice ( $n=10 /$ group) were intraperitoneally pretreated with $200 \mu \mathrm{l}$ of saline or PIC at various doses $1 \mathrm{~h}$ before the intraperitoneal injection of compound 48/80. Mortality (\%) within $1 \mathrm{~h}$ following compound $48 / 80$ injection is represented as the number of dead mice $\mathrm{x} 100 /$ total number of experimental mice.

Protein extraction and western blot analysis. HMC-1 cells were washed twice with PBS and resuspended for protein extraction with reagents from an Intron Pro-Prep Protein Extraction kit. Processed samples were subjected to $8 \%$ SDS-PAGE and transferred to a PVDF membrane. The membrane was then washed with 5\% skim milk in PBST (0.05\% Tween-20 in PBS) for $1 \mathrm{~h}$ at room temperature and then incubated overnight with anti-MAPK antibodies. After the blot was washed 3 times with PBST, it was incubated with the secondary antibody for $1 \mathrm{~h}$. The antibody-specific proteins were then visualized using an enhanced chemiluminescence detection kit (Amersham Biosciences), and the blot was exposed to X-ray film.

Statistical analysis. Statistical significances were compared between each treated group and analyzed by the Student's t-test. Data from the experiments are presented as means \pm SEM. The numbers of independent experiments assessed are provided in the figure legends.

\section{Results}

Effect of PIC on systemic and local anaphylaxis. To determine the effect of PIC on allergic reaction, an in vivo model of a systemic reaction was used. Compound $48 / 80(8 \mathrm{mg} / \mathrm{kg})$ was used as a model of induction for a systemic fatal allergic reaction. After the intraperitoneal injection of compound 48/80, the mice were monitored for $1 \mathrm{~h}$, after which the mortality rate was determined. As shown in Table II, injection of compound $48 / 80$ into mice induced fatal shock in $100 \%$ of the animals. When PIC was intraperitoneally administered at concentrations ranging from 10 to $1000 \mathrm{mg} / \mathrm{kg}$ BW $1 \mathrm{~h}$ prior to exposure to compound $48 / 80$, the mortality rate was dose-dependently reduced. In addition, the mortality of mice administered PIC $(1000 \mathrm{mg} / \mathrm{kg}$ ) following compound 48/80 injection increased in a time-dependent manner (Table III). The effect of PIC on the compound 48/80-induced serum histamine release was investigated. PIC was administered at concentrations ranging from 10 to $1000 \mathrm{mg} / \mathrm{kg} 1 \mathrm{~h}$ prior to the compound
Table III. Time-dependent effect of PIC on compound 48/80induced systemic anaphylaxis.

\begin{tabular}{lccc}
\hline $\begin{array}{l}\text { PIC treatment } \\
(\mathrm{mg} / \mathrm{kg} \mathrm{BW})\end{array}$ & $\begin{array}{c}\text { Time } \\
(\mathrm{min})\end{array}$ & $\begin{array}{c}\text { Compound 48/80 } \\
(8 \mathrm{mg} / \mathrm{kg} \mathrm{BW})\end{array}$ & $\begin{array}{c}\text { Mortality } \\
(\%)\end{array}$ \\
\hline None (saline) & - & + & 100 \\
1000 & 5 & + & 30 \\
& 10 & + & 70 \\
& 15 & + & 100 \\
\hline
\end{tabular}

Mice ( $\mathrm{n}=10$ /group) were intraperitoneally pretreated with $200 \mu \mathrm{l}$ of saline or PIC $(1000 \mathrm{mg} / \mathrm{kg}) 0,5,10$ and $15 \mathrm{~min}$ after the intraperitoneal injection of compound 48/80. Mortality (\%) within $1 \mathrm{~h}$ following compound $48 / 80$ injection is represented as the number of dead mice x 100/total number of experimental mice.
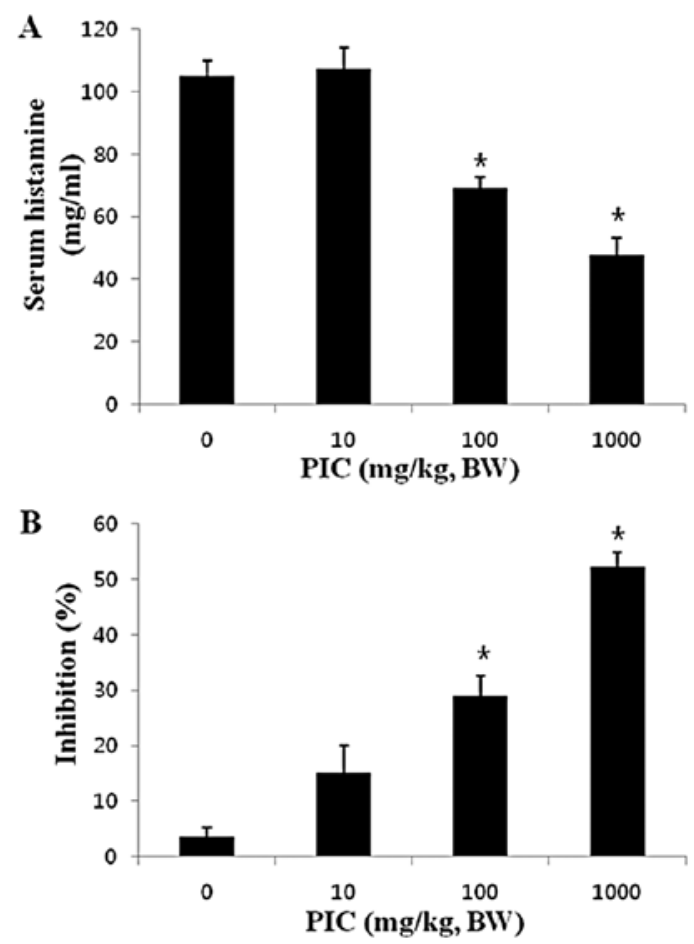

Figure 2. Effect of piceatannol on serum histamine release and PCA reactions. (A) Groups of mice ( $\mathrm{n}=10 /$ group) were intraperitoneally pretreated with $200 \mu \mathrm{l}$ of saline or PIC. PIC was administered at various doses $1 \mathrm{~h}$ prior to the injection of compound $48 / 80$. The compound $48 / 80$ solution was administered intraperitoneally to the group of mice. The blood was obtained from the heart of each mouse, and the histamine content was measured by histamine assay kit. (B) PIC was intraperitoneally administered $1 \mathrm{~h}$ prior to the challenge with antigen. Each amount of dye was extracted as described in Materials and methods and measured by spectrophotometry. Each bar represents the mean \pm SEM of three independent experiments. Significant difference at ${ }^{*} \mathrm{p}<0.05$.

$48 / 80$ injection. Injection of compound 48/80 caused a marked increase in serum histamine release, and this induction was inhibited by PIC treatment in a dose-dependent manner (Fig. 2A). To confirm the anti-allergic effects of PIC, we used an IgE-mediated passive cutaneous anaphylaxis (PCA) model. PCA is one of the most important in vivo models of 

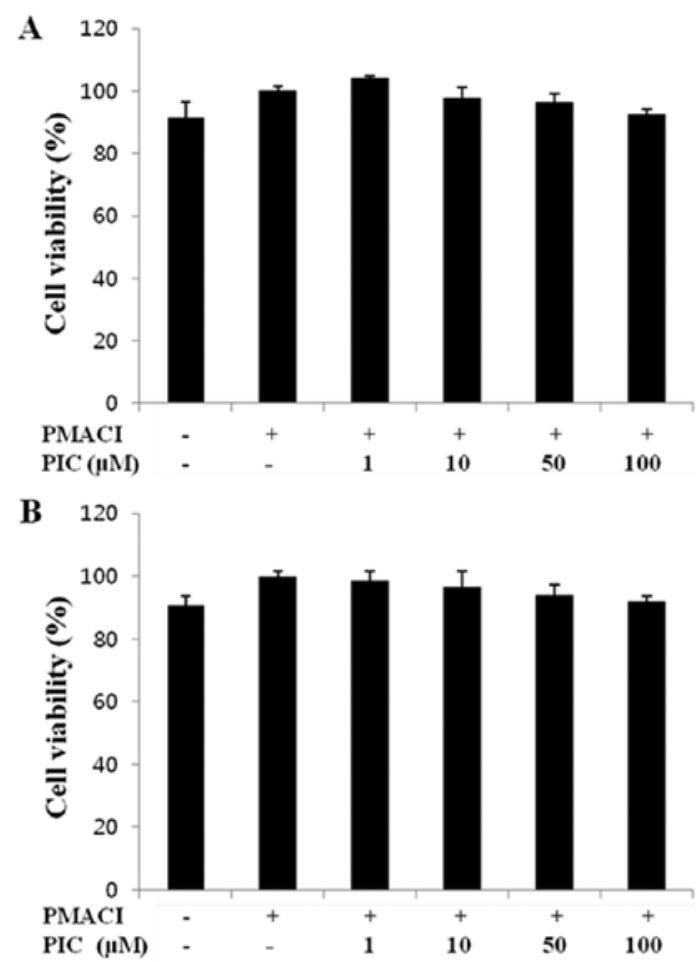

Figure 3. Effect of piceatannol on cell viability in PMA- plus A23187induced HMC-1 (A) and RBL-2H3 (B) cells. Cells were pretreated with PIC $(1,10,50$, and $100 \mu \mathrm{M})$ for 30 min prior to PMA $(50 \mathrm{nM})+\mathrm{A} 23187(1 \mu \mathrm{M})$ (PMACI) stimulation. Each bar represents the mean \pm SEM of three independent experiments. "Significant difference at $\mathrm{p}<0.05$.

local allergic reaction. A local extravasation was induced by a local injection of $\operatorname{IgE}$ followed by an antigenic challenge. Intraperitoneal injection of PIC dose-dependently inhibited the PCA reaction (Fig. 2B).

Effect of PIC on cell viability. To evaluate the cytotoxic effects of PIC, an MTT viability assay in HMC-1 and RBL-2H3 cells was performed. Fig. 3 shows the viability of cells incubated $24 \mathrm{~h}$ after stimulation in the absence or presence of PIC $(1,10,50$ and $100 \mu \mathrm{M})$. Stimulation and treatment with PIC did not appreciably affect cell viability. Kang et al (27). reported on the cytotoxic effect of resveratrol, the precursor of PIC, on HMC-1 cells using the MTT assay. Resveratrol was not cytotoxic against HMC-1 and RBL-2H3 cells up to $100 \mu \mathrm{M}$.

Effect of PIC on histamine release. The release of chemical mediators such as histamine plays an important role in allergic inflammation (27). Therefore, we examined the effects of PIC on histamine release. We evaluated the ability of PIC to inhibit PMA and A23187-induced histamine release from RBL-2H3 cells (Fig. 4A). Histamine ( $188 \mathrm{ng} /$ $\mathrm{ml}$ ) was detectable in unstimulated cells; however, RBL-2H3 cells released $\sim 275 \mathrm{ng} / \mathrm{ml}$ of histamine when stimulated with PMA plus A23187. PIC inhibited PMA and A23187-induced histamine release in a dose-dependent manner as follows: $22.14 \%$ inhibition at $1 \mu \mathrm{M}, 30.18 \%$ inhibition at $10 \mu \mathrm{M}$, $51.92 \%$ inhibition at $50 \mu \mathrm{M}$ and $61.61 \%$ inhibition at $100 \mu \mathrm{M}$ (Fig. 4B).
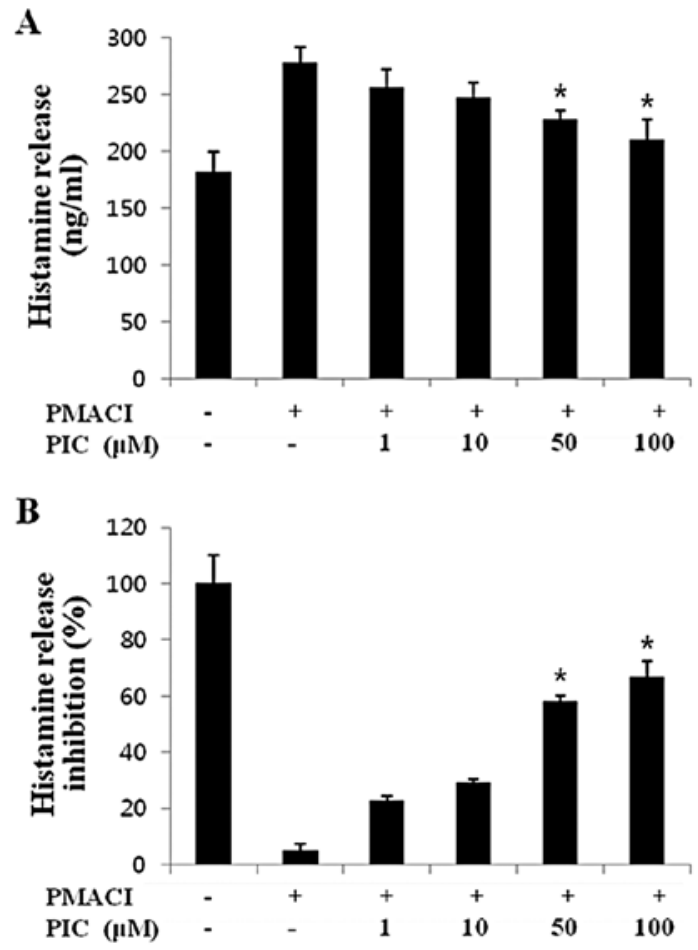

Figure 4. (A) Effect of piceatannol on histamine release in stimulated RBL-2H3 cells. (B) Effect of piceatannol on histamine release inhibition in stimulated RBL-2H3 cells. Cells were pretreated with PIC $(1,10,50$, and $100 \mu \mathrm{M})$ for 30 min prior to PMA $(50 \mathrm{nM})+\mathrm{A} 23187(1 \mu \mathrm{M})(\mathrm{PMACI})$ stimulation. Each bar represents the mean \pm SEM of three independent experiments. *Significant difference at $\mathrm{p}<0.05$.

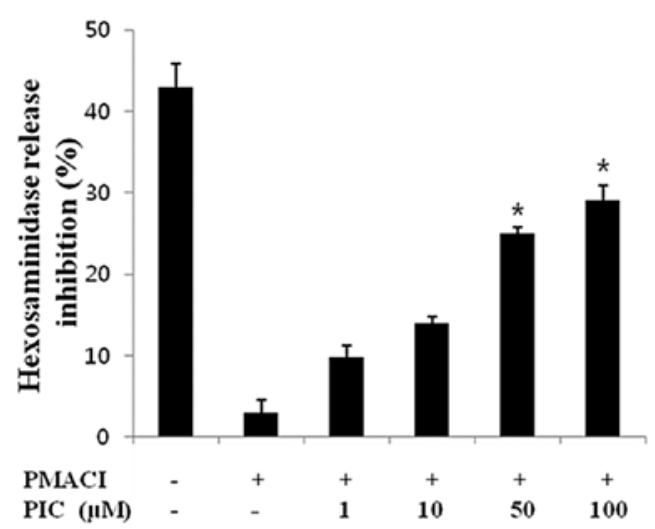

Figure 5. Effect of piceatannol on $\beta$-hexosaminidase release inhibition in stimulated RBL-2H3 cells. Cells were pretreated with PIC $(1,10,50$, and $100 \mu \mathrm{M})$ for $30 \mathrm{~min}$ prior to PMA $(50 \mathrm{nM})+\mathrm{A} 23187(1 \mu \mathrm{M})$ (PMACI) stimulation. Each bar represents the mean \pm SEM of three independent experiments. *Significant difference at $\mathrm{p}<0.05$.

Effect of PIC on $\beta$-hexosaminidase release. The rat basophilic leukemia RBL-2H3 cell line, a tumor analog of mast cells, exhibits phenotypic characteristics of mucosal mast cells. After stimulation with antigens, cells release $\beta$-hexosaminidase, which is a marker of mast cell degranulation. Thus, RBL-2H3 cells are considered a good model for the comprehensive study of events induced by multivalent allergens in mast cells (27-29). In our study, PIC strongly suppressed PMA plus A23187-induced degranulation in a dose-dependent manner in the RBL-2H3 cells (Fig. 5). 
A
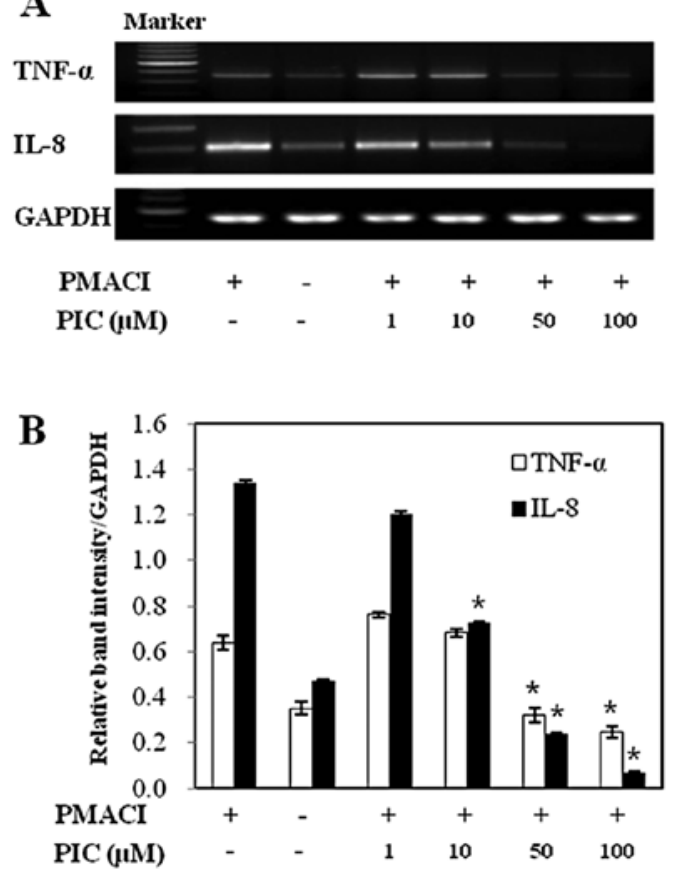

Figure 6. Effect of piceatannol on pro-inflammatory cytokine (TNF- $\alpha$ and IL-8) mRNA expression in PMA- plus A23187-induced HMC-1 cells (A) and its relative intensity (B). Cells were pretreated with PIC $(1,10,50$ and $100 \mu \mathrm{M})$ for $30 \mathrm{~min}$ prior to PMA $(50 \mathrm{nM})+\mathrm{A} 23187(1 \mu \mathrm{M})(\mathrm{PMACI})$ stimulation. Expression of cytokine mRNAs was analyzed by RT-PCR. Band intensity for each gene expressions was normalized against GAPDH.

Effect of PIC on pro-inflammatory cytokine expression. TNF- $\alpha$ and IL- 8 are the most important pro-inflammatory cytokines. Therefore, we tested the effect of PIC on the gene expression of TNF- $\alpha$ and IL-8 induced by PMA plus A23187 in HMC-1 cells. Gene expression of pro-inflammatory cytokines was then analyzed using RT-PCR. HMC-1 cells were treated with PMA plus A23187 in the presence or absence of PIC $(1,10,50$ and $100 \mu \mathrm{M})$ for $2 \mathrm{~h}$ and then harvested for transcriptional analysis via RT-PCR. Enhanced TNF- $\alpha$ and IL-8 mRNA expression induced by PMA plus A23187 was inhibited by pretreatment of HMC-1 cells with PIC. Pretreatment with PIC at concentrations of 1, 10,50 and $100 \mu \mathrm{M}$ inhibited PMA and A23187-induced gene expression of TNF- $\alpha$ and IL-8. Gene expression of TNF- $\alpha$ and IL- 8 was decreased in a dose-dependent manner by pretreatment with PIC (Fig. 6).

Effect of PIC on pro-inflammatory cytokine production. To confirm the effect of PIC on the gene expression of pro-inflammatory cytokines, culture supernatants were assayed for TNF- $\alpha$ and IL- 8 levels by ELISA methods. HMC-1 cells were pretreated with PIC $(1,10,50$ and $100 \mu \mathrm{M})$ before stimulation with PMA $(50 \mathrm{nM})$ and A23187 $(1 \mu \mathrm{M})$ for $8 \mathrm{~h}$, and culture supernatants were analyzed using ELISA. As shown in Fig. 7A and $\mathrm{B}$, the concentrations of TNF- $\alpha$ and IL- 8 were considerably increased after HMC-1 cells were stimulated with PMA plus A23187. PIC pretreatment strongly inhibited these increases in a dose-dependent manner.

Effect of PIC on activation of mitogen-activated protein kinases (MAPKs). MAPK pathways play a crucial role in the regulation
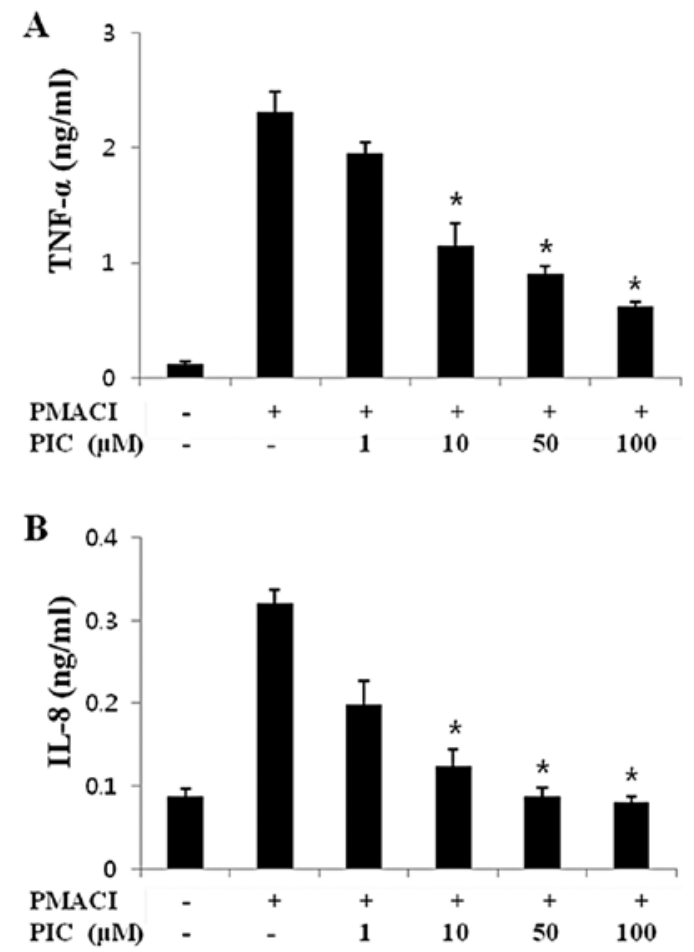

Figure 7. Effect of piceatannol on pro-inflammatory cytokine secretion (TNF- $\alpha$ and IL-8) by PMA- plus A23187-induced HMC-1 cells. Cells were pretreated with PIC $(1,10,50$ and $100 \mu \mathrm{M})$ for 30 min prior to PMA $(50 \mathrm{nM})+\mathrm{A} 23187$ $(1 \mu \mathrm{M})$ (PMACI) stimulation. Each bar represents the mean $\pm \mathrm{SEM}$ of three independent experiments. "Significant difference at $\mathrm{p}<0.05$.

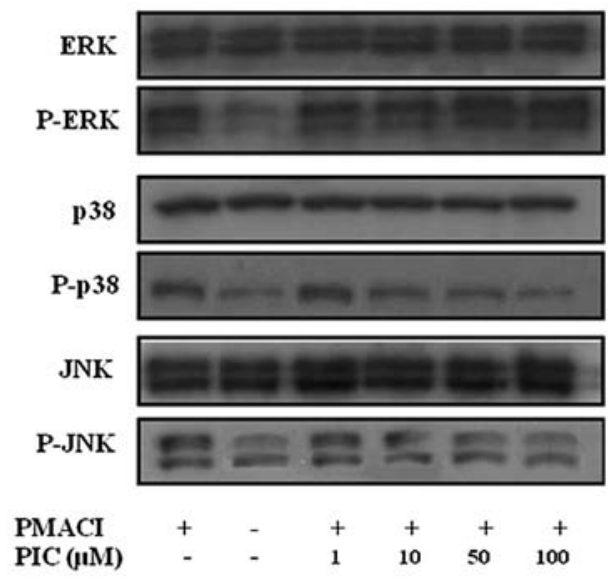

Figure 8. Effect of piceatannol on activation of MAPKs. Cells were pretreated with PIC $(1,10,50$ and $100 \mu \mathrm{M})$ for 30 min prior to PMA $(50 \mathrm{nM})+\mathrm{A} 23187$ $(1 \mu \mathrm{M})$ (PMACI) stimulation. Phosphorylation of MAPKs was analyzed by western blotting.

of pro-inflammatory molecules affecting cellular responses. In order to elucidate the mechanisms underlying the effects of PIC, we examined the possible effects of PIC on the activation of MAPKs (Fig. 8). The stimulation of HMC-1 cells with PMA plus A23187 resulted in increased phosphorylation of all 3 types of MAPKs (p38, JNK, and ERK) 30 min post-treatment. Pretreatment with PIC $(1,10,50$ and $100 \mu \mathrm{M})$ attenuated PMA and A23187-induced p38 and JNK MAPK activation but did not significantly affect the phosphorylation of ERK. 


\section{Discussion}

The present study revealed that piceatannol (PIC) demonstrates anti-allergic inflammatory properties via regulation of MAPK signaling. Anaphylaxis is a life-threatening syndrome induced by the sudden systemic release of inflammatory mediators, such as histamine, heparin and various cytokines from mast cells (30). PIC inhibited compound 48/80-induced systemic anaphylaxis and histamine release from mast cells. Mice administered PIC were protected from IgE-mediated local allergic reaction. PCA is one of the most important in vivo models of anaphylaxis. These results indicate that PIC inhibited mast cell-mediated allergic reactions. In addition, PIC decreased phorbol-12-myristate 13-acetate and calcium ionophore A23187 (PMACI)-stimulated expression of pro-inflammatory cytokines. These results suggest that PIC may be useful in the treatment of allergic inflammatory diseases.

Histamine was originally considered as a mediator of acute inflammatory and immediate hypersensitivity responses. It has been reported that histamine affects chronic inflammation and regulates several essential events of the immune response such as immune cell maturation, polarization and lymphocyte responsiveness (31). Histamine also induces actin polymerization and chemotaxis (32). Compound 48/80, the synthetic mast cell stimulator, increases the permeability of the lipid bilayer membrane by perturbation in the membrane. These studies indicate that an increase in membrane permeability may be essential for the release of the mediator from mast cells. In our study, PIC dose-dependently reduced compound $48 / 80$-induced histamine release from mast cells. Taken together, we speculate that PIC stabilizes the actin polymerization of the membrane, thus preventing the compound 48/80-induced membrane perturbation. Seow et al (28) reported that, at 30 and $100 \mu \mathrm{M}$, PIC significantly suppressed ovalbumin-induced histamine release from lung fragments by 30 and $74 \%$, respectively.

Another study on flavonoids reported that at $30 \mu \mathrm{M}$, fisetin, kaempferol, myricetin, quercetin and rutin inhibited the release of histamine from antigen-stimulated RBL-2H3 cells (29). Those results were similar to an investigation using PMACI-stimulated RBL-2H3 cells, in which fisetin, kaempferol, myricetin, quercetin and rutin efficiently inhibited histamine release. While fisetin, kaempferol, quercetin and rutin significantly reduced antigen- and PMACI-induced histamine release from mast cells, astragalin was not effective (29). Matsuda et al (33) studied the inhibitory effects of 15 stilbenes and 4 dihydrostilbenes on the release of $\beta$-hexosaminidase in RBL-2H3 cells. 3,5,40-Trimethylpiceatannol ( $\mathrm{IC}_{50}, 2.1 \mu \mathrm{M}$ ) exhibited the most potent activity, followed by trimethylresveratrol $(5.1 \mu \mathrm{M})$, rhapontigenin $(11 \mu \mathrm{M})$, isorhapontigen $(12 \mu \mathrm{M})$, tetramethylpiceatannol $(13 \mu \mathrm{M}), 3,30,40$-trimethylpiceatannol $(16 \mu \mathrm{M})$, resveratrol $(17 \mu \mathrm{M})$, desoxyrhapontigenin $(18 \mu \mathrm{M})$ and PIC $(24 \mu \mathrm{M})$. Their activities were stronger than those of 2 anti-allergic compounds, tranilast $(0.28 \mathrm{mM})$ and ketotifen fumarate $(0.22 \mathrm{mM}) .12$-trans-stilbene $(>100 \mu \mathrm{M})$, which lacks oxygen functions on the ring, was inactive. Thus, the effects of substitution on aromatic rings of stilbenes indicated that stilbenes substituted with methoxyl groups at the 3-, 5- and 40-positions exhibited higher activity than those with hydroxyl groups.
Mast cells play a critical role in inflammation and protective immune responses by releasing preformed vasoactive amines, prostaglandins, cytokines and chemokines (34). Various inflammatory cytokines such as TNF- $\alpha$, IL-1 $\beta$, IL-6 and IL-8, which act as triggers or regulators in allergic inflammatory response, are crucial for mast cell development (35). TNF- $\alpha$ is a well-known inflammatory factor produced mainly by macrophages, and plays a critical role in systemic inflammation (36). It is also a potent inducer of other inflammatory cytokines, including IL-1 $\beta$, IL-6, IL-8 and GM-CSF. IL-6 is one of the most important mediators of a multifunctional pro-inflammatory cytokines, and the major cytokine produced by activated mast cells (37). These studies indicate that the inhibition of pro-inflammatory cytokines is one of the critical points of reduced allergic inflammatory symptoms. In our study, PIC inhibited gene expression and secretion of cytokines. These results imply that PIC has anti-allergic inflammatory effects by controlling pro-inflammatory cytokines in mast cells.

The MAPK cascade is an important signaling pathway in immune responses. The MAPK signaling cascade regulates important cellular processes including gene expression, cell proliferation, cell survival and death and cell mobility (38). The precise signaling pathways among the three types of MAPKs, i.e., ERK, JNK and p38 are still unclear. However, the induction of inflammatory cytokine genes requires activation of all three types of MAPKs. In this study, PMACIinduced activation of p38 and JNK MAPKs was reduced by PIC. The data suggest that PIC has an inhibitory activity on all three MAPKs and downstream cytokine production. Kang et al (27) examined the possible effects of resveratrol on activation of MAPKs. Stimulation of HMC-1 cells with PMA plus A23187 resulted in increased phosphorylation of all 3 types of MAPKs, p38, JNK, ERK, and activation of protein kinase C (PKC) 15-30 min post-treatment. Resveratrol attenuated PMA plus A23187-induced ERK 1/2, but did not affect the phosphorylation of JNK 1/2 and p38 MAPK. In addition, resveratrol had no effect on PMA plus A23187-induced PKC activation.

PIC is an anti-inflammatory, immunomodulatory and antiproliferative stilbene that has been shown to interfere with the cytokine signaling pathway (39). In the present study, we provided evidence that PIC inhibits mast cell-mediated allergic inflammatory reactions and their possible mechanisms such as histamine release and MAPK for pro-inflammatory cytokines. The results obtained in the present study reveals that PIC contributes to the prevention or treatment of mast cellmediated allergic inflammatory diseases.

\section{Acknowledgements}

Yu-Jin Ko and Chung-Ho Ryu were supported by a scholarship from the BK21 Program, the Ministry of Education, Science and Technology, Korea.

\section{References}

1. Bhat KPL, Kosmeder JW II and Pezzuto JM: Biological effects of resveratrol. Antiox Redox Signal 3: 1041-1064, 2001.

2. ElAttar TM and Virji AS: Modulating effect of resveratrol and quercetin on oral cancer cell growth and proliferation. Anticancer Drugs 10: 187-193, 1999. 
3. Kawada N, Seki S, Inoue M and Kuroki T: Effect of antioxidants, resverarol, quercetin, and $\mathrm{N}$-acetylcysteine, on the functions of cultured rat hepatic stellate cells and Kupffer cells. J Hepatol 27 $1265-1274,1998$

4. Wadsworth TL and Koop DR: Effect of wine polyphenolic quercetin and resveratrol on pro-inflammatory cytokine expression in RAW 264.7 macrophages. Biochem Pharmacol 57: 941-949, 1999

5. Martinez J and Moreno JJ: Effect of resveratrol, a natural polyphenolic compound, on reactive oxygen species and prostaglandin production. Biochem Pharmacol 59: 865-870, 2000.

6. Ferrigni NR, McLaughlin JL, Powell RG and Smith CR Jr: Use of potato disc and brine shrimp bioassays to detect activity and isolate piceatannol as the antileukemic principle from the seeds of Euphorbia lagascae. J Nat Prod 47: 347-352, 1984.

7. Wieder T, Prokop A, Bagci B, et al: Piceatannol, a hydroxylated analog of the chemopreventive agent resveratrol, is a potent inducer of apoptosis in the lymphoma cell line BJAB and in primary, leukemic lymphoblasts. Leukemia 15: 1735-1742, 2001.

8. Geahlen RL and McLaughlin JL: Piceatannol (3,4,3',5'-tetrahydroxy-trans-stilbene) is a naturally occurring protein-tyrosine kinase inhibitor. Biochem Biophys Res Commun 165: 241-245, 1989.

9. Cheong H, Ryu SY and Kim KM: Anti-allergic action of resveratrol and related hydroxystilbenes. Planta Med 65: 266-274, 1999.

10. Shishodia S and Aggarwal BB: Nuclear factor-kappaB activation: a question of life or death. J Biochem Mol Biol 35: 28-40, 2002.

11. Thakkar K, Geahlen RL and Cushman M: Synthesis and protein tyrosine kinase inhibitory activity of polyhydroxylated stilbene analogues of piceatannol. J Med Chem 36: 2950-2955, 1993.

12. Wang BH, Lu ZX and Polya GM: Inhibition of eukaryote serine/ threonine-specific protein kinases by piceatannol. Planta Med 64: 195-159, 1998

13. Oliver JM, Burg DL, Wilson BS, McLaughlin JL and Geahlen RL: Inhibition of mast cell FcR1-mediated signaling and effector function by the syk selective inhibitor, Piceatannol. J Biol Chem 269: 296-297, 1994.

14. Tsai SK, Hung LM, Fu YT, et al: Resveratrol neuroprotective effects during focal cerebral ischemia injury via nitric oxide mechanism in rats. J Vasc Surg 46: 346-353, 2007.

15. Rocha-Gronzălez HI, Ambriz-Tututi M and Granados-Soto V: Resveratrol: A natural compound with pharmacological potential in neurodegenerative diseases. CNS Neurosci Ther 14: 234-247, 2008.

16. Zhu Z, Homer RJ, Wang Z, et al: Pulmonary expression of interleukin-13 causes inflammation, mucus hypersecretion, subepithelial fibrosis, physiologic abnormalities, and eotaxin production. J Clin Invest 103: 779-788, 1999.

17. Royer B, Varadaradjalou S, Saas P, et al: Autocrine regulation of cord blood-derived human mast cell activation by IL-10. J Allergy Clin Immunol 108: 80-86, 2001.

18. Stassen M, Müller C, Arnold M, et al: IL-9 and IL-13 production by activation mast cells is strongly enhanced in the presence of lipopolysaccharide: NF-kappa B is decisively involved in the expression of IL-9. J Immunol 166: 4391-4398, 2001.

19. Barmes PJ and Adcock I: Anti-inflammatory actions of steroids: molecular mechanisms. Trends Pharmacol Sci 14: 436-441, 1993.

20. Mukaida N: Interleukin-8: an expanding universe beyond neutrophil chemotaxis and activation. Int $\mathbf{J}$ Hematol 72 391-398, 2000.
21. Rasmussen $\mathrm{H}$ and Goodman DB: Relationships between calcium and cyclic nucleotides in cell activation. Physiol Rev 57: 421-509, 1977.

22. White JR, Pluznik DH, Ishizaka $\mathrm{K}$ and Ishizaka T: Antigeninduced increase in protein kinase $\mathrm{C}$ activity in plasma membranes of mast cells. Proc Natl Acad Sci USA 82: 8193-8197, 1985.

23. Kim MS, Lim WK, Park RK, et al: Involvement of mitogenactivated protein kinase and NF-kappaB activation in $\mathrm{Ca}^{2+}$ induced IL-8 production in human mast cells. Cytokine 32: 226-233, 2005

24. Kim SH, Kwon TK and Shin TY: Antiallergic effects of Vitis amurensis on mast cell-mediated allergy model. Exp Biol Med 233: 192-199, 2008.

25. Kim SH, Park SB, Kang SM, et al: Anti-allergic effects of Teucrium japonicum on mast cell-mediated allergy model. Food Chem Toxicol 47: 398-403, 2009.

26. Kim SH, Lee S, Kim IK, et al: Suppression of mast cell-mediated allergic reaction by Amomum xanthiodes. Food Chem Toxicol 45: 2138-2144, 2007.

27. Kang $\mathrm{OH}$, Jang HJ, Chae HS, et al: Anti-inflammatory mechanism of resveratrol in activated HMC-1 cells: pivotal roles of NF- $\kappa$ B and MAPK. Pharmacol Res 59: 330-337, 2009.

28. Seow CJ, Chue SC and Wong WS: Piceatannol, a syk-selective tyrosine kinase inhibitor, attenuated antigen challenge of guinea pig airway in vitro. Eur J Pharmacol 443: 189-196, 2002.

29. Park HH, Lee SY, Son HY, et al: Flavonoids inhibit histamine release and expression of proinflammatory cytokine in mast cells. Arch Pharm Res 31: 1303-1311, 2008.

30. Kemp SF and Lockey RF: Anaphylaxis: a review of causes and mechanisms. J Allergy Clin Immunol 110: 341-348, 2002.

31. Jutel M, Blaser K and Akdis CA: Histamine in allergic inflammation and immune modulation. Int Arch Allergy Immunol 137: 82-92, 2005.

32. Jutel M, Watanabe T, Akdis M, Blaser K and Akdis CA: Immune regulation by histamine. Curr Opin Immunol 14: 735-740, 2002.

33. Matsuda H, Tewtrakul S, Morikawa $\mathrm{T}$ and Yoshikawa $\mathrm{M}$ : Anti-allergic activity of stilbenes from Korean rhubarb (Rheum undulatum L.): structure requirements for inhibition of antigeninduced degranulation and their effects on the release of TNF-alpha and IL-4 in RBL-2H3 cells. Bioorg Med Chem 12: 4871-4876, 2004

34. Hu ZQ, Zhao WH and Shimamura T: Regulation of mast cell development by inflammatory factors. Curr Med Chem 14: 3044-3050, 2007.

35. Galli SJ, Kalesnikoff J, Grimbaldeston MA, Piliponsky AM, Williams CM and Tsai M: Mast cells as 'tunable' effector and immunoregulatory cells: recent advances. Annu Rev Immunol 23: 749-786, 2005 .

36. Hu ZQ, Kobayashi K, Zenda N and Shimamura T: Tumor necrosis factor alpha and interleukin-6 triggered mast cell development from mouse spleen cells. Blood 89: 526-533, 1997.

37. Burd PR, Rogers HW, Gordon JR, et al: Interleukin 3-dependent and independent mast cells stimulated with $\operatorname{IgE}$ and antigen express multiple cytokines. J Exp Med 170: 245-257, 1989.

38. Arbabi S and Maier RV: Mitogen-activated protein kinases. Crit Care Med 30: S74-S79, 2002

39. Ashikawa K, Majumdar S, Banerjee S, Bharti AC, Shishodia S and Aggarwal BB: Piceatannol inhibits TNF-induced NF-kappaB activation and NF-kappaB-mediated gene expression through suppression of IkappaBalpha kinase and p65 phosphorylation. J Immunol 169: 6490-6497, 2002. 